\title{
Patterns of bioconstruction in the cheilostome bryozoan Schizoporella errata: the influence of hydrodynamics and associated biota
}

\author{
Silvia Cocito ${ }^{1, *}$, Francesca Ferdeghini $^{1}$, Carla Morri ${ }^{2}$, C. Nike Bianchi ${ }^{1}$ \\ 'Marine Environment Research Centre, ENEA Santa Teresa, PO Box 316, 19100 La Spezía, Italy \\ ${ }^{2}$ DipTeRis (Zoologia), Università di Genova, Via Balbi 5, 16126 Genova, Italy
}

\begin{abstract}
In the region of La Spezia (Ligurian Sea, Italy), the bryozoan Schizoporella errata forms sizeable buildups, termed 'giant colonies' or 'compound colonies' by previous investigators. Buildups were encrusting (up to $40 \mathrm{~cm}$ wide) with flat or bumpy surfaces in an exposed site, and erect (more than $20 \mathrm{~cm}$ high) branching anastomosed structures in a semi-exposed and in a sheltered site. The buildup architecture was significantly different in the 3 sites, with higher vertical development and number of branches per $\mathrm{dm}^{2}$ in the sheltered site. The internal structure of the buildups was also different: densely packed, extensive laminated sheets developed in the sheltered site; loosely packed, concentric sheets alternating with small cavities filled with sediment and shells of associated organisms were found in the semi-exposed and exposed sites. Functional groups could be recognised among the biota associated with $S$. errata buildups. The constructional pattern was interpreted as resulting from both interactions with other organisms and hydrodynamic conditions. While in the exposed site $S$. errata showed no vertical growth, in the sheltered site soft-bodied erect organisms formed the frame around which $S$. errata deposited a multilayered structure, which eventually caused the death and disappearance of the immured organisms. Breakage of branch tips by episodic disturbance and repeated binding through a complex array of budding patterns by $S$. errata resulted in tall buildups which preserved no trace of the soft-bodied organisms. Because of the role they played, these may therefore be defined as 'ghost frame-builders'.
\end{abstract}

KEY WORDS: Bryozoa - Bioconstruction · Growth forms · Hydrodynamics · Associated biota - Mediterranean Sea

\section{INTRODUCTION}

Present-day biotic reefs are built mostly by corals and calcareous algae, but in ancient times several other phyla were also important (Fagerström 1987). The involvement of Bryozoa in forming reefs has varied considerably through geological time; they were principal frame-builders in some Palaeozoic reefs. However in present-day coral reefs, bryozoans frequently play different accessory roles related to their growth form, but normally do not function as the principal frame-building organisms (Cuffey 1972, 1974, 1977).

\footnotetext{
•E-mail: cocito@estosf.santateresa.enea.it
}

Nevertheless, some living bryozoans are able to build large masses and be significant rock-formers (Kosich \& Cuffey 1978, Bijma \& Boeschotten 1985, Scholz \& Hillmer 1995, Taylor \& Allison 1998). Species of the genus Schizoporella, whose bioherms are known from both the past and the Recent, are among the most important builders (Pouyet 1971, Cuffey \& Fonda 1976, Beatty et al. 1998). In the Gulf of La Spezia (Italy), Ferdeghini et al. (2000) found sizeable living masses of S. errata (Waters 1878). This species is widely distributed in warm-temperate to tropical waters, but Hayward \& Ryland (1979) explained its occurrence around the British Isles as owing to passive introduction amongst fouling communities on ships. The same explanation possibly holds for its occurrence in the Mediterranean Sea, as most records of its pres- 
ence are from harbours (Gautier 1962, Maluquer 1985). There, the species mostly thrives in shallow, calm water with high organic matter content, but may also inhabit areas with some hydrodynamics (Gusso Chimenz \& Rivosecchi Taramelli 1972). Studies with artificial panels recorded diameter growth rates of up to $16 \mathrm{~cm}$ in $1 \mathrm{yr}$ and showed highest reproduction and settlement during warmer months (Geraci 1974, Montanaro \& Tursi 1983).

In their preliminary work, Ferdeghini et al. (2000) provided a first description of the structure of Schizoporella errata buildups at La Spezia. In the present paper we interpret the morphological variability of the same buildups as being plastic developmental responses to changes in environmental factors. We hypothesise that transition from multiserial encrustations to erect, branched buildups is related to the presence, in sheltered situations, of soft-bodied, erect organisms. Changes in constructional patterns of $S$. errata are interpreted as the results of the interaction with both these organisms and hydrodynamic conditions.

\section{MATERIALS AND METHODS}

Study area. The study was carried out in the region of La Spezia, an area under intense human pressure located in the Eastern Ligurian Sea (Fig. 1). The movement of water masses in the region is consistent with the Ligurian current, flowing towards the north-west (Astraldi \& Gasparini 1992). In the channel between Palmaria and Tino Islands, the water flows mostly westward reaching a velocity of $80 \mathrm{~cm} \mathrm{~s}^{-1}$ (Cocito et al. 1998). Nutrient concentrations are significantly higher inside the Gulf of La Spezia (Cattini et al. 1992) than in the oligotrophic waters off the islands (Boniforti et al. 1993).

Three sites were selected according to their relative degree of exposure. The first, most exposed site, was located at Tino Island, at the western border of the Gulf; the second in a semi-exposed area in the harbour of La Spezia, on the breakwater delimiting the portcomplex offshore; and the third in the inner part of the sheltered, small harbour of Lerici, where Schizoporella errata grew close to a sewer drain. The terms 'exposed' and 'sheltered' are used here in a relative sense. According to the fetch-energy index of Hummon (1989), which assigns an energy value of $100 \%$ to a wave reaching the coast perpendicularly from an infinite fotch distance. Tine is subject to a rolative wave energy of $42, \mathrm{La}$ Spezia of $\vartheta$ and Lerici of $3 \%$. At Tino, waves come mostly from the south-west and can reach a height of $6.5 \mathrm{~m}$ (Cocito \& Sgorbini 2000). The La Spezia breakwater is rarely hit by southern waves higher than $1 \mathrm{~m}$ (Bassano et al. 2000), whereas waves are virtually absent in the harbour of Lerici.

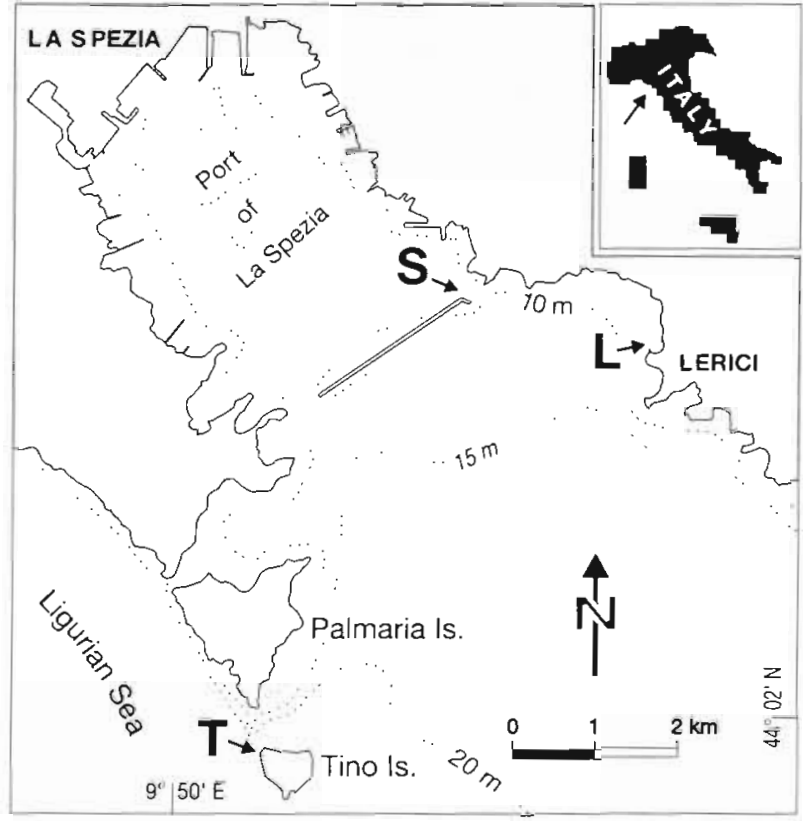

Fig. 1 Study area and location of sampling sites. T; Tino Island, exposed site; S: La Spezia harbour, semi-exposed site; and L: Lerici harbour, sheltered site

Sampling and laboratory methods. A total of 96 individual buildups (or large fragments) of Schizoporella errata was collected at 0.3 to $8 \mathrm{~m}$ depthsthrough snorkelling and SCUBA diving in June and July 1997 -by scraping the substrate with a hammer and chisel. 32 samples were taken from Tino Island, 33 from La Spezia breakwater and 31 from Lerici harbour. After collection, each sample was bagged in polyethylene and preserved by freezing

In the laboratory, the volume of the buildups was calculated by placing each sample in a cylinder filled with water and measuring the water displacement. Height, length and width were measured to the nearest mm. The number of branches per equivalent surface unit $\left(\mathrm{dm}^{2}\right)$ was computed by dividing the total number of branches by $V^{2 / 3}$ (where $V=$ volume in $\mathrm{dm}^{3}$ ). The order of branching was estimated by counting the number of bifurcations along each branch axis.

Buildups were photographed to keep a record of their external morphology, then sawn to examine their internal structure. Their basal thickness was measured at as many points as possible with a vernier calliper. Living zooid layers wore recogniscd visuilly and counted under a dissecting microscope along cross sections.

Growth form was described by the height index $(h)$ of Pichon (1987):

$$
h=2 H /(D+d)
$$


where $H=$ maximum height of the buildup; $D=$ maximum length; $d=$ maximum width.

Differences in $h$, relative branch number, highest branching order and basal thickness among sites were tested with the Kruskal-Wallis 1-way ANOVA, whereas the Mann-Whitney $U$-test was used for pairwise site comparison (Sokal \& Rohlf 1981).

The biota associated with the buildups was collected and identified to species whenever possible, taking into account only the organisms larger than $5 \mathrm{~mm}$. Functional groups within this associated biota were defined according to their motility, position in the buildups and potential role in the constructional process.

\section{RESULTS}

\section{Occurrence}

At Tino Island, the most exposed site, Schizoporella errata colonised the rocky bottom down to $8 \mathrm{~m}$ depth, developing large (up to $40 \mathrm{~cm}$ ) encrustations with flat or bumpy surfaces. Their substratum cover never exceeded $5 \%$ in a community dominated by algae. In the semi-exposed site on La Spezia breakwater, the species inhabited rocky blocks as well as concrete surfaces down to $5 \mathrm{~m}$, together with barnacles and mussels. S. errata colonies were numerous but relatively small ( $<30 \mathrm{~cm}$ wide), covering in total about $20 \%$ of the substratum. The landing-wharf structures of Lerici harbour were totally colonised $(100 \%$ of substratum cover) by large and erect compound colonies more than $20 \mathrm{~cm}$ high.

\section{Buildup morphology}

Buildups from the 3 sites showed different gross morphologies (Fig. 2). At Tino, they had an encrusting growth form with only a few squat branches. Lerici buildups were predominantly erect, with long and slender branches that formed complex and anastomosed structures with open or closed tips. La Spezia showed intermediate features.

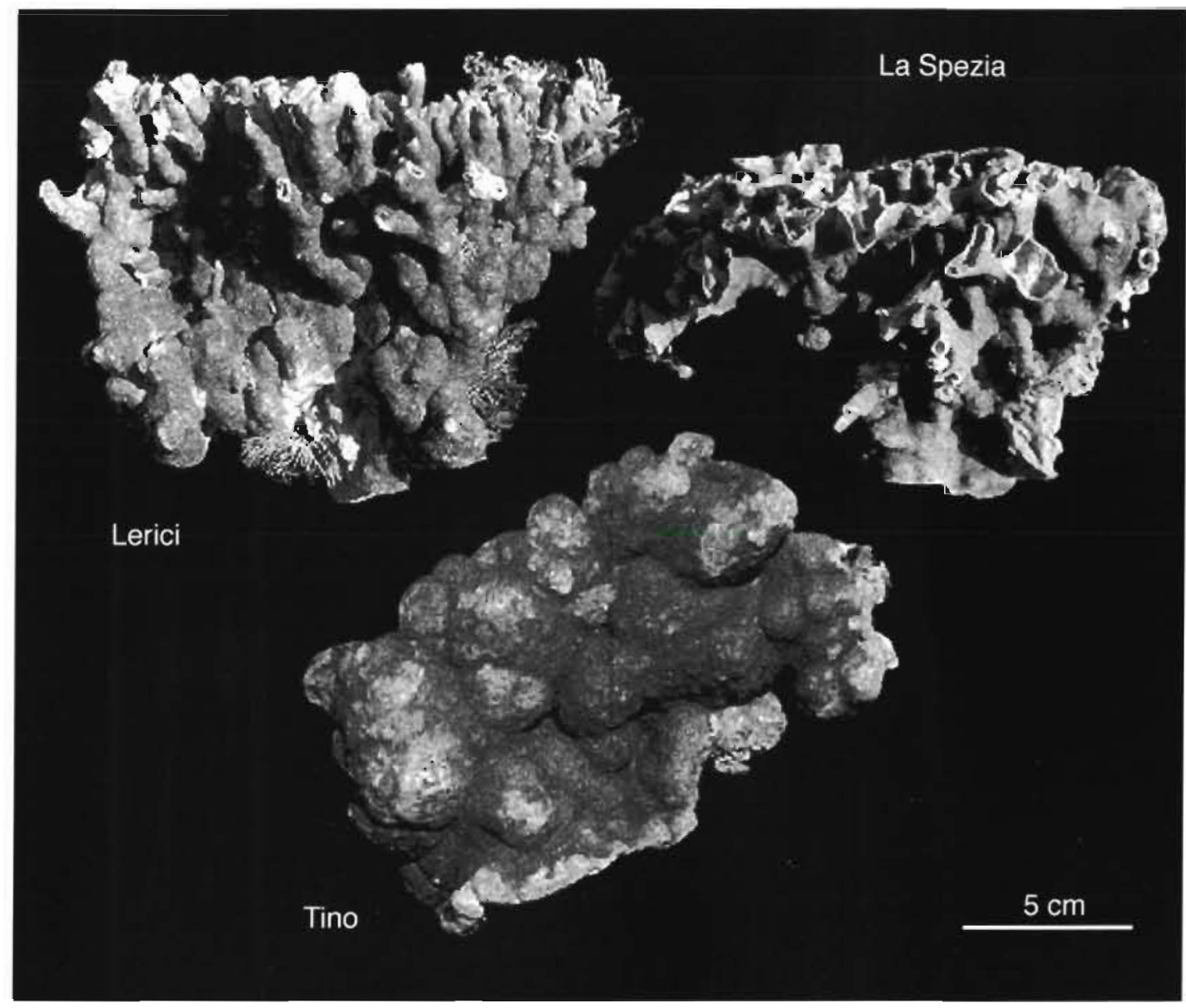

Fig. 2. Typical morphologies of Schizoporella errata buildups from the 3 sites 
Pichon's height indices for Schizoporella errata buildups from the 3 sites (Table 1) were significantly different (Kruskal-Wallis 1-way ANOVA, p $<0.0001$ ). All sites differed from each other (Mann-Whitney $U$ test, $p<0.0001$ for all the 3 pairwise comparisons). At Tino, all buildups had $h$ values below 0.8 , indicating stout forms, as were most of those from La Spezia Lerici buildups exhibited the widest range of $h$ values, but many exceeded 1.0 (Fig. 3).

The number of branches per surface unit and the branching order (Table 1) were also different among the 3 sites (Kruskal-Wallis 1-way ANOVA, $p<0.0001$ ). However, while the numbers of branches in the 3 sites were different Mann-Whitney $U$-test: Tino vs La Spezia, $p=0.001$; La Spezia vs Lerici, $p=0.014$; Tino vs Lerici, $p<0.0001$ ), branching order was lower at Tino than at La Spezia and Lerici (Mann-Whitney $U$-test, $p<0.0001$ ) but not significantly different between La Spezia and Lerici (Mann-Whitney $U$-test, $p=0.143$ ). Although fusion between closed branch tips complicated counting, branching order reached the 4 th degree at La Spezia and the 5 th degree at Lerici (Table 1).

\section{Internal structure}

Dissection of specimens from the 3 sites showed differences in the skeletal packing patterns of the basal

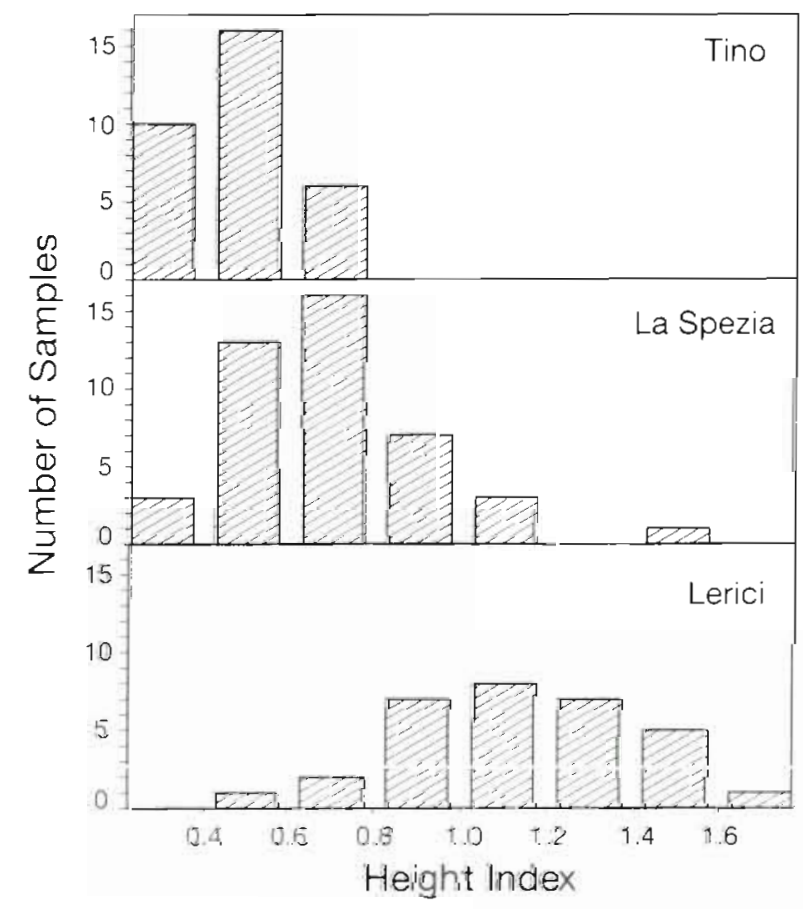

Fig. 3. Frequency distribution of height index in Schizoporella errata from the 3 sites. Height index was calculated according to the formula of Pichon (1978)
Table 1 Summary of measurements on Schizoporella errata buildups from the 3 sites

\begin{tabular}{lccc|}
\hline & Tino & La Spezia & Lerici \\
\hline Height index & & & \\
Mean & 0.48 & 0.69 & 1.13 \\
SD & 0.12 & 0.21 & 0.43 \\
No. of samples & 32 & 33 & 31 \\
Min. & 0.30 & 0.35 & 0.08 \\
Max. & 0.74 & 1.18 & 2.73 \\
Branch number $\times \mathbf{d m}^{2}$ & & & \\
Mean & 0.02 & 0.17 & 0.44 \\
SD & 0.04 & 0.29 & 0.54 \\
No. of samples & 32 & 33 & 31 \\
Min. & 0 & 0 & 0 \\
Max. & 0.15 & 1.16 & 2.36 \\
Branching order & & & \\
Mean & 0.2 & 1.6 & 2.2 \\
SD & 0.5 & 1.6 & 1.6 \\
No. of samples & 32 & 33 & 31 \\
Min. & 0 & 0 & 0 \\
Max. & 2 & 4 & 5 \\
Basal thickness $(\mathrm{mm})$ & & & \\
Mean & 21.3 & 23.2 & 44.9 \\
SD & 10.5 & 21.3 & 28.6 \\
No. of measurements & 53 & 35 & 27 \\
Min. & 3 & 5 & 13 \\
Max. & 42 & 104 & 104 \\
& & & \\
\hline
\end{tabular}

portions. Samples from the exposed site were composed of a repetitive sequence of extensive, laminated, tightly packed sheets (Fig. 4a)

A. more open framework was evident in the masses from the semi-exposed and, especially, the sheltered site (Fig 4b). There, masses were nodular, formed of densely packed (sometimes concentric) sheets alternating with small cavities. Individuals of sessile epibionts, such as algae, hydroids, serpulids and barnacles, were found encased (and dead) between layers of Schizoporella errata (Fig. 5)

Basal thickness was greater at Lerici and La Spezia than at Tino (Table 1). Kruskal-Wallis 1-way ANOVA showed significant differences among the 3 sites $(p<0.0001)$. Mann-Whitney $U$-tests showed that differences were significant between Lerici and La Spezia $(p<0.0001)$ and Tino and Lerici $(p<0.0001)$, but not between La Spezia and Tino $(p=0.423)$.

The transverse sections of branches showed different filling or encrustation patterns. Some branches were tip-closed, filled by concentric, densely packed layers, except for a small cylindrical hole remaining at the centre. Organic debris or sediment occurred inside the hole. Other branches appeared as hollow, thin tubes constructed by a few layers surrounding erect sessile organisms, such as algae, hydroids, mussels and barnacles (Fig. 5). 


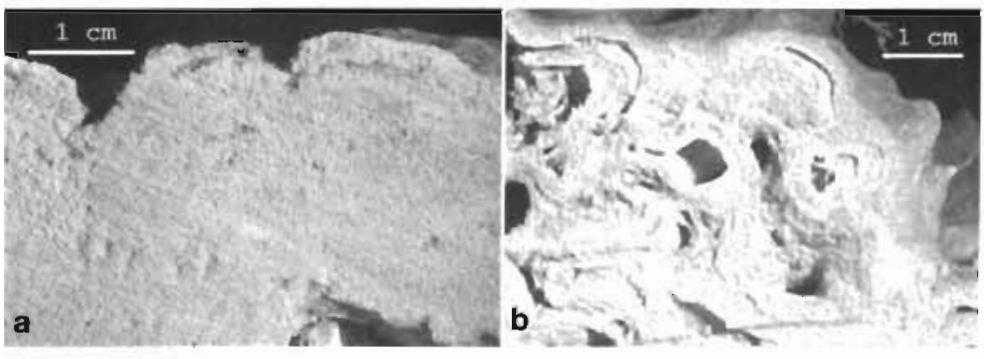

Fig. 4. Sections of the basal portions of Schizoporella errata buildups, showing different skeletal packing pattern at 2 sites: (a) Tino and (b) Lerici

3 sites studied, the tallest buildups of Schizoporella errata formed mainly in Lerici harbour, where erect growth may be favoured by crowding. Lerici was the most sheltered site. Other bryozoan bioconstructions are reported to occur in lagoons (Poluzzi 1980, Bijma \& Boeschotten 1985, Sprigg \& Bone 1993) and in submarine caves (Harmelin 1985, Scholz \& Hillmer 1995). Thus bryozoans apparently conform to other non-anthozoan builders, such as serpulids, which form reefs mostly in quiet environments (Bianchi et al.

\section{Associated biota}

Species composition of the biota associated to Schizoporella errata buildups showed important differences among the 3 sites, and especially between Tino and the remaining two. However, different species apparently played the same role in $S$. errata buildups from the 3 sites (Table 2).

Buildups from Tino Island had few associated fauna when compared with the other 2 sites. Barnacles were found embedded within bumps at the outer surface. Similarly, some algal bushes were found within squat branches. All other organisms were found mostly in the basal part

At La Spezia, algae, hydroids, mussels and sabellid polychaetes were found protruding from the slender branches with open tips. Algal turf and the bushy bryozoan Scrupocellaria reptans (the most abundant species found here) covered extensive portions of the buildups.

Scrupocellaria reptans and Bugula neritina occurred in dense clumps of many colonies on the external surface of the buildups from Lerici. As at La Spezia, hydroids and algae were found inside slender branches, mussels in flared branches, and sponges and bivalves within cavities. Serpulids and ascidians were more abundant than at the other 2 sites.

Other sedentary and motile organisms were numerous at the 3 sites. The former settled on the dead portions or filled in cavities; the latter found shelter within branches or dwelt within the sediment accumulated in the interstices.

\section{DISCUSSION}

Although large dimensions and significant substratum cover were reached in all
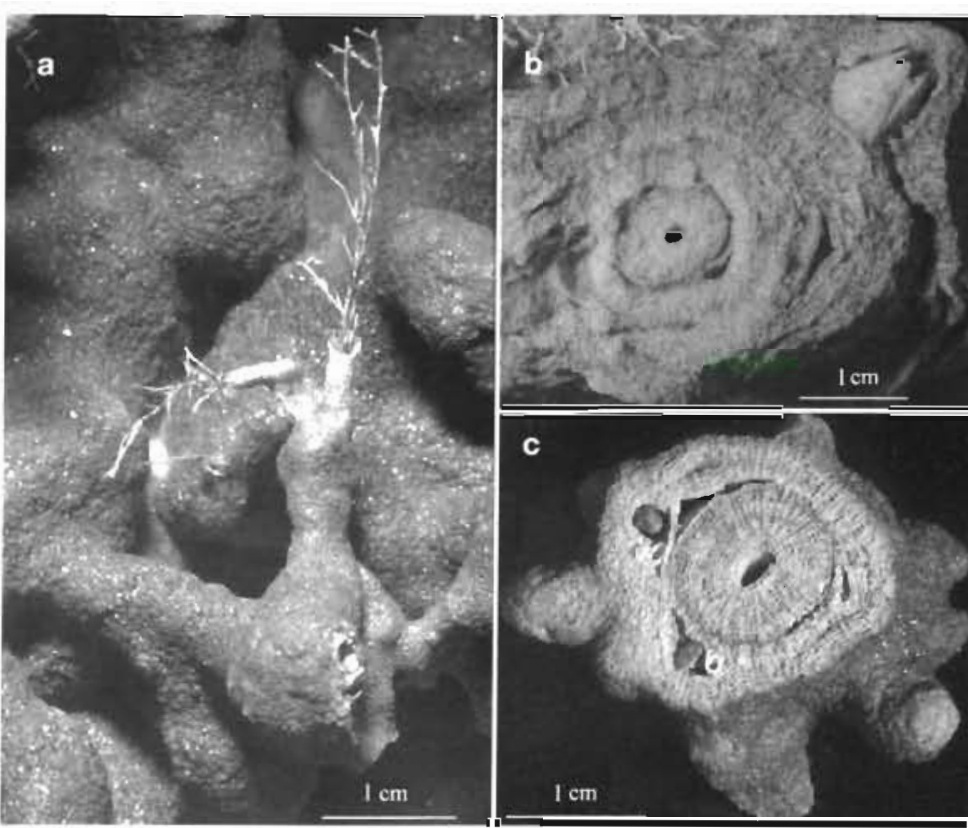

Fig. 5. Branch morphology of Schizoporella errata colonies from Lerici. (a) branch development around a hydroid stem. Transverse sections of well-developed branches, showing concentric layering and encased shells of dead organism, such as (b) barnacles, and (c) serpulids and small mussels 
Table 2. Differences in species composition of the assoclated biota in the 3 sites, based on organism habit and growth form

\begin{tabular}{|c|c|c|c|}
\hline & Tino & La Spezia & Lerici \\
\hline \multicolumn{4}{|l|}{ Sessíle } \\
\hline Erect & Brown algae (Cystoseira sp.) & $\begin{array}{l}\text { Articulate (Corallina elongata) } \\
\text { and filamentous red algae; } \\
\text { hydrolds (Eudendrium sp.), } \\
\text { sabellid polychaetes } \\
\text { (Branchiomma luctuosum), } \\
\text { bryozoans (Margaretta cereoides, } \\
\text { Scrupocellaria reptans) }\end{array}$ & $\begin{array}{l}\text { Green (Ulva sp.) and articulate } \\
\text { red algae (Corallina elongata), } \\
\text { hydroids (Eudendrium sp.), } \\
\text { bryozoans (Bugula neritina, } \\
\text { Scrupocellaria reptans) }\end{array}$ \\
\hline Turf & $\begin{array}{l}\text { Filamentous green algae, } \\
\text { hydroid mat }\end{array}$ & Filamentous red and green algae & Filamentous green algae \\
\hline Massive & $\begin{array}{l}\text { Sponges (Ircinia sp.), barnacles } \\
\text { (Balanus perforatus). dscidians } \\
\text { (Microcosmus sp.) }\end{array}$ & $\begin{array}{l}\text { Sponges (Haliclona sp.), } \\
\text { mussels (Mytilus galloprovincialls), } \\
\text { barnacles (Balanus perforatus), } \\
\text { ascidians (Polycarpa pomaria) }\end{array}$ & $\begin{array}{l}\text { Mussels (Mytilus galloprovincialis), } \\
\text { barnacles (Balanus perforatus, } \\
\text { B. amphitrite), ascidians } \\
\text { (Phallusia fumigata, Polycarpa } \\
\text { pomaria, Styela plicata) }\end{array}$ \\
\hline Encrusters & $\begin{array}{l}\text { Serpulids, bryozoans } \\
\text { (Watersipora subovoidea) }\end{array}$ & $\begin{array}{l}\text { Sponges (Hymeniacidon } \\
\text { sanguinea), hydroids } \\
\text { (Sertularella ellisii), serpulids, } \\
\text { spirorbids, bryozoans } \\
\text { (Watersipora subovoidea) }\end{array}$ & $\begin{array}{l}\text { Sponges (Hymeniacidon sanguinea), } \\
\text { bivalves (Anomia ephippium), } \\
\text { serpulids, spirorbids }\end{array}$ \\
\hline \multicolumn{4}{|l|}{ Sedentary } \\
\hline Cavity fillers & $\begin{array}{l}\text { Sponges, bivalves (Arca noae, } \\
\text { Striarca lactea) }\end{array}$ & $\begin{array}{l}\text { Sponges, bivalves } \\
\text { (Petricola lithophaga) }\end{array}$ & $\begin{array}{l}\text { Sponges, bivalves } \\
\text { (Petricola lithophaga) }\end{array}$ \\
\hline \multicolumn{4}{|l|}{ Motile } \\
\hline Dwellers & $\begin{array}{l}\text { Errant polychaetes, shrimps } \\
\text { (Alpheus sp.), echinoderms } \\
\text { (Ophiotrix fragilis, } \\
\text { Coscinasterias tenuspina), } \\
\text { fishes (Lepadogaster } \\
\text { lepadogaster, Parablennius } \\
\text { rouxi) }\end{array}$ & $\begin{array}{l}\text { Gastropods (Calliostoma sp.), } \\
\text { errant polychaetes, echinoderms } \\
\text { (Ophiotrix fragilis) }\end{array}$ & $\begin{array}{l}\text { Gastropods (Gibbula varia, } \\
\text { Nassarius incrassatus), errant } \\
\text { polychaetes (Harmotoe } \\
\text { areolata, Lepidonotus clava, } \\
\text { Nereis sp.), amphipods, crabs } \\
\text { (Eriphia verrucosa, Pilumnus } \\
\text { hirtellus, Porcellana platycheles) }\end{array}$ \\
\hline
\end{tabular}

cant vertical development was achieved by both a thicker basal portion and the production of erect branches.

Branching formed a spatially complex structure, providing habitat for other sessile and motile organisms, as already described by Bradstock \& Gordon (1983), Maluquer (1985) and Ferdeghini \& Cocito (1999). Habitat provision by biologically generated complexity has been demonstrated as playing an important role in maintaining and enhancing marine biodiversity (Thompson et al. 1996). Building a rigid and erect framework, colonies of Schizoporella errata modify habitat characteristics and may thus be qualified as 'ecosystem engincers' (Jones et al. 1904).

Conversely, the associated organisms may theriselves contribute to the consolidation of the buildup, not only adding their skeletal structures (Reguant \& Zamarreno 1987, Moissette \& Pouyet 1991), but also playing many of the functional roles described by Fagerstrom
(1991). Our observations suggest that competition for the substratum between Schizoporella errata and the other sessile species played a major and previously undescribed role, especially at La Spezia and Lerici. $S$. errata is a strong interference competitor, able to overgrow other organisms (Osman 1977, Sutherland 1978). Erect organisms may resist overgrowth (Buss
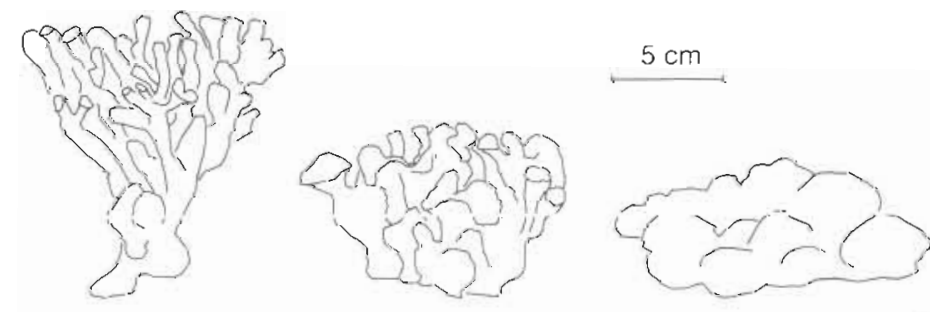

Exposure

Fig. 6. Change in growth form of Schizoporella errata buildups according to exposure gradient in La Spezia region 


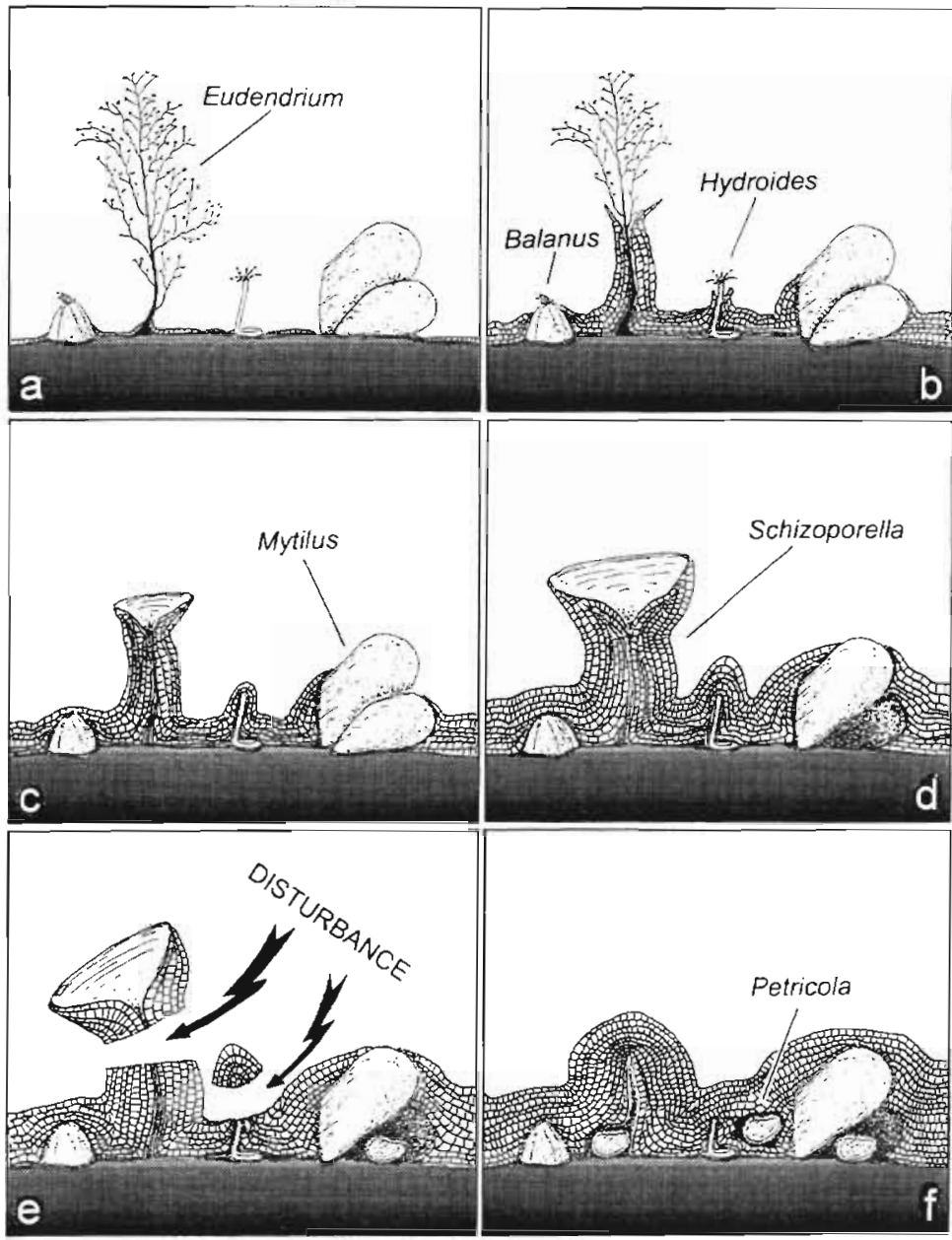

Fig. 7. Hypothetical pattern of framework construction in Schizoporella errata buildups: (a) $S$. errata colonises bare substratum among other sessile organisms; (b) to (d) S. errata overgrows the other species which eventually die, leaving branches with closed or open and flared tips; (e) episodic disturbance may break away the fragile apical portions of the erect branches; (f) final structure of the multilayered buildup of $S$. errata, the original morphology being little or no longer recognizable (see 'Discussion']

1981, McKinney \& Jackson 1989) when bushy and grouped in dense clumps of colonies, as shown by Scrupocellaria reptans and Bugula neritina. When erect organisms grow isolated, $S$. errata easily expands above their stems and forms encrusting layers around them, thus creating cylindrical branches; this happened, for instance, with the hydroid Eudendrium racemosum. In this way the erect organisms may serve as a template for building an erect framework

The possible process of buildup growth may be summarised as follows (Fig. 7). As a first step, Schizoporella errata colonies grow side-by-side with barnacles, mussels, algae and hydroids colonising the substratum with single-layered encrusting sheets (Fig. 7a). As free substratum becomes exhausted, S. errata morphology changes from unilamellar to multilamellar, owing to an array of budding patterns (Lidgard 1985, Ristedt 1996), including self-overgrowth (McKinney \& Jackson 1989). This leads to broad encrustations that expand above and unite the framework created by other organisms into the overall structure (Fig. 7b). Although partially covered by the bryozoan layers, these organisms survive for some time. When growing around tall, arborescent organisms such as hydroids, S. errata forms cylindrical branches which flare at their distal end because of the swinging apical parts of the arborescent organism. On wave-swept rocks in the exposed site, this swinging movement must be so continuous and intense that such branches do not develop at all. Eventually, all the organisms overgrown and surrounded by $S$. errata die (Fig. 7c). Soft-bodied organisms leave no skeletal remnants and in this case the cylindrical branches of $S$. errata appear hollow (Fig. 7d). When an episodic physical or other disturbance breaks away the fragile apical portions of those branches (Fig. 7e), the bryozoan repairs breakage through frontal and lateral budding processes, giving the branch tip a completely different shape. At this stage, $S$ errata appears to be the only organism responsible for the construction of an erect frame, whereas the contribution of shelled organisms to the thickness and solidity of the basal crust is clearly recognisable (Fig. 7f).

Studying the zoarial morphology of Schizoporella violacea (a junior synonym of S. errata, according to Hayward \& Ryland 1979), Pouyet (1971) also observed hollow branches and, finding no organism remnants inside the cavities, concluded that the erect branching growth was independent of the associated biota. Our observations do not agree with Pouyet's interpretation, and lead to the hypothesis that erect growth was achieved in sheltered sites through the contribution of associated organisms, rather than by $S$. errata itself. According to our interpretation, reduced hydrodynamics is a necessary but not sufficient condition for the formation of tall buildups of $S$. errata. This formation requires the presence of erect, associated organisms that act as a support for repeated binding by the bryozoan. If soft-bodied, these organisms disappear after complete overgrowth by $S$. errata. We call these organ- 
isms 'ghost frame-builders' and consider the process of 'ghost frame-building' a peculiar form of bioimmuration, i.e. the organic overgrowth of sessile organisms by encrusting animals with mineralised skeletons (Taylor 1990). Contrary to what routinely happens with bioimmuration which usually produces a precise mould, in this case, such as in the case of bryozoan building tubes around hermit crab simbionts (Taylor 1994), the exact shape of the soft-bodied organism is not preserved in the final structure, especially when morphology is altered by breakage and the repairing capacity of $S$ errata. Ghost frame-building permits the vertical growth of sheet-like encrusting organisms and represents a further example of the complexity of the interactions among epibiosis, competition and physical disturbance in the encrusting sequences and growth patterns (Wahl 1989, Mckinney 1995, Spjeldnaes \& Moisette 1997, Kidwell \& Gyllenhaal 1998). It may be a process of more general occurrence with significant ecological and palaeontological implications (Smith 1995, Nebelsick et al. 1997). Clearly, further investigation is needed to test our hypothesis and to see whether it can be extended to other habitats and/or organisms.

Acknowledgements. We thank S. Sgorbini (La Spezia) for participating in sampling, P. L. Ferdeghini (La Spezid) for helping with sample dissection, and A. M. De Biasi (Livorno) for identitying polychaetes. A. Balduzzi (Genova), S. Fraschetti (Lecce). S. Pouyet (Lyon), S. Reguant (Barcelona), and J. B. C. Jackson (Panama) gave advice and/or provided bibliography; R. J. Cuffey (Pennsylvanial and P. D. Taylor (London) also improved the manuscript. Research on Schizoporella errata falls within the scope of the project CLIMBIOCCA l'influence of CLIMatic change on the activity of BIOConstructional organisms and on their role in the CArbon cycle of the manne environment') of the Marine Environment Research Centre of ENEA. This work benefited from a grant on 'Marine Biodiver. sity (MURST). F.F. was supported by a joint PhD fellowship ENEA-University of Pisa.

\section{LITERATURE CITED}

Astraldi M. Gasparini GP (1992) The seasonal characteristics of the circulation in the North Mediterranean Basin and their relationship with the atmospheric-climatic conditions. J Geophys Res 97(C6):9531-9540

Bassano E, Boniforti R, Pezzani A (2000) Parametri meteorologici e idrologici. In: Peroni C (ed) Sistema informativo e di monitoraggio marino costiero. Rapp ENEA-Provincia La Spezia 35:19-59

Beatty WL, Cuffey RJ, Hageman SJ, Smith AM (1998) Paleodepth and paleohabitat from bryozoan colony growth forms (Early Miocene. Southern Australia). Geol Soc Am Ais Proy Júli:2

Bianchi CN, Aliani S, Morri C (1995) Present-day serpulid reets, with relerence to an on-going research project on Ficopomatus enigmaticus. Pubbl Serv Cieol Luxembourg $29: 61-65$

Bijma J. Boeschatten GJ (1985) Recent bryozoan reefs and stromatolite development in brackish inland lakes, SW Netherlands. Senckenb Marit 17(1-3):163-185
Boniforti R, Emaldi P, Ferraiolu R, Maspero M, Nair R (1993 Preliminary data on DMS concentration in seawater samples collected from the La Spezia Gulf (Ligurian Sea). In: Restelli G, Angeletti G (eds) Dimethylsulphide: oceans atmosphere and climate. Kluwer Academic Publ, London, p 163-173

Bradstock M. Gordon DP (1983) Coral-like bryozoan growths in Tasman Bay, and therr protection to conserve commercial fish stocks. NZ J Mar Freshw Res 17:159-163

Buss WL (1981) Group living, competition, and the evolution of cooperation in a sessile invertebrate. Science 213:10121014

Cattıni E. Nair R, Peroni C, Rossi G (1992) Trophic conditions of waters in the Gulf of La Spezia (Ligurian Sea). Rapp Comm Int Mer Médıt 23:95-99

Cocito S, Ferdeghini F (1999) Morphological variations in Pentapora fascialis (Cheilostomatida, Ascophorina). Proc 11th Int Bryozool Assoc Conf STRI Balboa, Panama, January 1998, p $176-181$

Cocito S, Sgorbin S (2000) Mortality of the bryozoan Pentapora fascialis in the Ligurian Sea (NW Mediterranean) after disturbance. In: Faranda FM, Guglielmo L, Spezie G (eds) Structure and processes in the Mediterranean ecosystems. Springer-Verlag (in press)

Cocito S. Sgorbini S, Bianchi CN $\{1998\}$ Zonation of a suspension-feeder assemblage on a temperate rocky shoal: the influence of water current and bottom topography. In Hawkins LE, Hutchinson E (eds) The responses of marne organisms to their environments. Southampton Oceanography Center, Southampton, p 183-192

Cuffey RJ (1972) The roles of bryozoans in modern coral reefs. Geol Rundschau 61:542-550

Cuffey RJ (1974) Delineation of bryozoan contructional roles in reefs from comparison of fossil bioherms and living reefs. Proc 2nd Int Coral Reef Symp 1:357 -364

Cuffey RJ (1977) Bryozoan contributions to reefs and bioherms through geologic time. Stud Geol 4:181-194

Cuffey RJ, Fonda SS (1976) 'Giant' Schizoporella-sedimentologically important cheilostome bryozoans in Pleistocene and Recent carbonate enviroments of Bermuda, the Bahamas, and Florida. Geol Soc Am Abs Prog 8(4):474-475

Fagerstrom JA (1987) The evolution of reef communities. John Wiley and Sons, New York

Fagerstrom JA (1991) Reef-building gulds and a checklıst for determining guild membership. Coral Reets 10:47-52

Ferdeghini F, Cocito S (1999) Biologically generated diversity in two bryozoan builtups. Biol Mar Medit 6(1):191-197

Ferdeghini F, Cocito S, Morn C, Bianchi CN (2000) Living bryozoan buildups: Schizoporella errata (Waters 1878) (Cheilostomatida, Ascophora) in northwestern Mediterranean. Proc 1tth Int Bryozool Assoc Conf STRI Balboa, Panama, January 1998 (in press)

Gautier YV (1962) Recherches écologiques sur les bryozoaires cheilostomes en Méditerranee occidentale. Recl Trav Stn Mar Endoume-Mars Fase Ser Suppl 1 38(24): $1-434$

Geraci S (1974) Infralittoral Bryozoa settled on artificial substrata in the Ligurian Sea. Doc Lab Geol Fac Sci Lyon 3 (2): $335-346$

Gusso Cnimenz C. Kivosecchı laramellı E (1972) Contributo alla conoscenza dei briozoi del porto di Civitavecchia. Atti $\checkmark$ Congr Naz Soc It Biol Mar SIBM Genova:66-101

Harmelin JG (1985) Bryozoan dominated assembiages in Mediterranean cryptic environments. In: Nielsen C. Larwood GP (eds) Bryozoa: ordovician to recent. Olsen \& Olsen, Fredensborg, p 135-143

Hayward PJ, Ryland IS (1979) British ascophoran bryozoans. 
In: Kermack DM, Barnes RSK (eds) Synopses of the British fauna. Academic Press, London

Hughes RN (1989) A functional biology of clonal animals. In: Calow P (ed) Functional biology series. Chapman \& Hall, London

Hummon WD (1989) The fetch-energy index: an a priori estimator of coastal exposure, applied to littoral marine gastrotricha of the British Isles. In: Ryland JS, Tyler PA (eds) Reproduction, genetics and distribution of marine organisms. Olsen \& Olsen, Fredensborg, p 387-393

Jones CG, Lawton JH, Chachak M (1994) Organisms as ecosystem engineers. Oikos 689:373-386

Kidwell SM, Gyllenhaal ED (1998) Symbiosis, competition and physical disturbance in the growth histories of Pliocene cheilostrome bryoliths. Lethaia 31:221-239

Kosich DF, Cuffey RJ (1978) Recognition of multilaminar cheilostome bryozoan species in modern Bermuda reefrock. Geol Soc Am Abs Prog 10(6):259

Lidgard S (1985) Budding process and geometry in encrusting cheilostome bryozoans. In: Nielsen C, Larwood GP (eds) Bryozoa: Ordovician to Recent. Olsen \& Olsen, Fredensborg, p 175-182

Maluquer P (1985) Algunas consideraciones sobre la fauna asociada a las colonias de Schizoporella errata (Waters, 1878) del puerto de Mahón (Menorca, Baleares). Publ Dept Zool Barcelona 11:23-28

McKinney FK (1995) Taphonomic effects and preserved overgrowth relationships among encrusting marine organisms. Palaios 10:279-282

McKinney FK, Jackson JBC (1989) Bryozoan evolution. Chicago University Press, Chicago

Moissette P. Pouyet S (1991) Bryozoan masses in the miocenepliocene and holocene of France, North Africa, and the Mediterranean. In: Bigey FP (ed) Bryozoa living and fossil. Soc Sci Nat Ouest France, Nantes, p 271-279

Montanaro C, Tursi A (1983) Settlement of bryozoans in the Mar Piccolo of Taranto (Southern Italy) from 1972 to 1982. Oebalia 9:91-103

Nebelsick JH, Schmid B, Stachowitsch M (1997) The encrustation of fossil and recent sea-urchin tests: ecological and taphonomic significance. Lethaia 30:271-284

Okamura B (1992) Microhabitat variation and patterns of colony growth and feeding in a marine bryozoan. Ecology 73:1502-1513

Osman RW (1977) The establishment and development of a marine epifaunal community. Ecol Monogr 47(1):37-63

Pichon $M$ (1987) Problems of measuring and mapping coral colonies. In: Stoddart DR, Johannes RE (eds) Coral reefs: research methods. Unesco, Norwich, p 219-231

Poluzzi A (1980) I briozoi membraniporiformi del delta setten-

Editorial responsibility: Roger Hughes (Contributing Editor), Bangor, Wales, UK trionale del Po. Atti Soc Ital Sci Nat Mus Civ Stor Nat Milano $121(1-2): 101-120$

Pouyet S (1971) Schizoporella violacea (Canu et Bassler 1930) (Bryozoa Cheilostomata): variations et croissance zoariale. Geobios 4(3):185-197

Reguant S, Zamarreno I (1987) Bryozoan bioherms on the Mediterranean continental shelf (Northeastern Spain). In: Ross JRP (ed) Bryozoa: present and past. Western Washington University, Bellingham, p 229-236

Riedl R (1971) Water movement: animals. In: Kinne $O$ (ed) Marine ecology, Vol 1(2). London University Press, Glasgow, p 1123-1156

Ristedt $\mathrm{H}$ (1996) Initial frontal budding in some nodular cheilostomes. In: Gordon D, Smith R, Grant-Mackie J (eds) Bryozoans in space and time. NIWA, Wellington, p 237-242

Scholz J, Hillmer G (1995) Reef-bryozoans and bryozoansmicroreefs: control factor evidence from the Philippines and other regions. Facies 32:109-144

Smith AM (1995) Palaeoenvironmental interpretation using bryozoans: a review. In: Bosence DWJ, Allison PA (eds) Marine palaeoenvironmental analysis from fossils. Geol Soc Spec Publ 83:231-243

Sokal RR, Rohlf FJ (1981) Biometry. WH Freeman and Company, New York

Spjeldnaes N, Moisette P (1997) Celleporid (bryozoan) thickets from the upper pliocene of the island of Rhodes, Greece. SEPM (Soc Sediment Geol) Spec Publ 56:263 270

Sprigg M, Bone Y (1993) Bryozoa in coorong-type lagoons southern Australia. Trans R Soc South Aust 117(1-2) $87-95$

Stach LW (1936) Correlation of zoarial form with habitat. $\mathrm{J}$ Geol 44:60-65

Sutherland JP (1978) Functional roles of Schizoporella and Styela in the fouling community at Beaufort, North Carolina. Ecology 59(2):257-264

Taylor PD (1990) Preservation of soft-bodied and other organisms by bioimmuration a review. Palaeontol J 33(1):1-17

Taylor PD (1994) Evolutionary palaeoecology of symbioses between bryozoans and hermit crabs. Hist Biol 9:157-205

Taylor PD, Allison PA (1998) Bryozoan carbonates through time and space. Geology 26:459-462

Thompson RC, Wilson BJ, Tobin ML, Hill AS, Hawkins SJ (1996) Biologically generated habitat provisioning and diversity of rocky shore organisms at a hierarchy of spatial scales. J Exp Mar Biol Ecol 202:73-84

Vogel S (1988) Life's devices: the physical world of animals and plants. Princeton University Press, Princeton

Wahl M (1989) Marine epibiosis. I. Fouling and antifouling: some basic aspects. Mar Ecol Prog Ser 58:175-189

Submitted: February 2, 1999; Accepted: July 27, 1999

Proofs received from author(s): January 14, 2000 